\title{
3. GEOPHYSICAL SIGNATURES OF THE AGULHAS FRACTURE ZONE RIDGE AND METEOR RISE, INDO-ATLANTIC BASIN 1
}

\author{
Carol A. Raymond and John L. LaBrecque ${ }^{2}$
}

\begin{abstract}
Sea Beam, single-channel seismic, gravimetric, and magnetic data were gathered on the Agulhas Ridge and Meteor Rise in the Indo-Atlantic Basin from aboard Robert D. Conrad to provide site survey data for the eastern part of the area investigated during ODP Leg 114 in the subantarctic South Atlantic. Results of the Conrad cruise are presented, including a revised bathymetric map of the area. These data define the morphology of the Agulhas Ridge and detail the structure of the Meteor Rise. The Agulhas Fracture Zone Ridge most likely formed as a result of changes in the direction of spreading in the Agulhas Basin. The morphology of the Meteor Rise is consistent with models for production of thick basaltic sequences at developing rifts. Geophysical data from the Meteor Rise may suggest a post-rift phase of volcanism that emplaced the high-relief seamount province on the eastern rim of the Meteor rise; this hypothesis deserves further investigation.
\end{abstract}

\section{INTRODUCTION}

The Agulhas Basin lies on the African plate, bounded by the Agulhas Fracture Zone to the north, the Southwest Indian Ridge to the south, the Meteor Rise on the west, and the Agulhas Plateau to the east (Fig. 1). The many anomalous bathymetric features within the Agulhas Basin testify to its dynamic tectonic history. The Meteor Rise, an aseismic plateau of Late Cretaceous-Paleocene age, lies conjugate to the Islas Orcadas Rise (presently east of the Falkland Plateau in the Georgia Basin) in a late Paleocene South Atlantic reconstruction (LaBrecque, 1986). The Agulhas Ridge, an elongate ridge following the trace of the Agulhas Fracture Zone, extends from the northern tip of the Meteor Rise toward the African margin and ends abruptly at $\sim 40^{\circ} \mathrm{S}, \sim 15^{\circ} \mathrm{E}$. The northern end of the Agulhas Ridge nearly intersects with an abandoned spreading center trending approximately north-northeast that became extinct during the early $\mathrm{Pa}$ leocene (approximately Chron C29) (du Plessis, 1977; Barker, 1979; LaBrecque and Hayes, 1979).

LaBrecque and Hayes (1979) postulated that the relief of the combined Agulhas and Falkland ridges created a formidable barrier to interbasin circulation of the antarctic and South Atlantic water masses during the Early Cenozoic. The degree to which circulation was inhibited can be inferred from the present depth and morphology of these anomalous bathymetric features. The eastern site survey for Ocean Drilling Program (ODP) Leg 114 was designed to investigate the morphology of the Agulhas Ridge and Meteor Rise and to collect geophysical information to determine probable mechanisms of formation of the Meteor and Islas Orcadas rises, as well as their tectonic evolution. The Agulhas Ridge is a fracture zone ridge. Fracture zone (FZ) ridges are linear topographic highs found to lie astride or adjacent to aseismic extensions of active transform faults (fracture zones), and also observed within transform fault plate boundaries. The Agulhas FZ Ridge actually exists within an abandoned transform fault, which was abandoned when the spreading axis in the Agulhas basin relocated farther west. The paleo-slip rate at the transform is poorly constrained because crust of the Cretaceous Quiet Zone lies on the northern side of the transform,

\footnotetext{
${ }^{1}$ Ciesielski, P. F., Kristoffersen, Y., et al., 1988. Proc. ODP, Init. Repts., 114: College Station, TX (Ocean Drilling Program).

2 Lamont-Doherty Geological Observatory of Columbia University, Palisades, NY 10964.
}

and anomaly identifications south of the transform are sparse, with the exception of the well determined anomaly $33 / 34$ lineations; the rate is estimated at $\sim 3 \mathrm{~cm} / \mathrm{yr}$. The age offset across the fossil transform is $\sim 45 \mathrm{Ma}$ at the eastern end of the Agulhas Ridge, decreases to zero towards the west, and increases again as the Meteor Ridge is approached (see Fig. 1).

The Meteor and Islas Orcadas rises appear to be large constructional features that were created at the South Atlantic spreading axis following a late Maestrichtian-early Paleocene westward jump of the spreading center. Consideration of simple subsidence models for the rises, where the paleodepth is calculated as the present depth corrected for sediment loading and the Parsons and Sclater (1977) subsidence coefficient, and the age is bracketed by the age of the seafloor on either side of the rise, indicates that the anomalously shallow rises were at or above sea level during the early Cenozoic and that the Meteor Rise remained in shallow water until at least the middle Eocene. Formation of normal oceanic crust resumed during Chron C24 ( $55 \mathrm{Ma}$; Kent and Gradstein, 1986), as is evident from the magnetic anomaly pattern bordering the western edge of the Meteor Rise. However, Eocene age crust west of the Meteor Rise is elevated by $\sim 600 \mathrm{~m}$ with respect to the expected seafloor depth for equivalent-age crust (see map and Hayes, 1988).

\section{DATA SUMMARY}

A track chart for Conrad 2710 is shown in Figure 1, on a schematic tectonic map of the region. The contours on the map were generated from an updated SYNBAPS digital bathymetry file. A revised bathymetric map of the region was prepared at a contour interval of $250 \mathrm{~m}$ from the site survey data, which improves the definition of the Agulhas FZ Ridge and Meteor Rise (Fig. 2, in back pocket). Figure 3 is a track chart illustrating the data used in compiling the map. Data sources include cruises of Conrad and Vema (Lamont-Doherty Geological Observatory), ARA Islas Orcadas and ARA Zapiola (Argentine Naval Hydrographic Service), and Atlantis II and Chain (Woods Hole Oceanographic Institution) and data provided by the Republic of South Africa. As is evident from the track chart, the data density is sparse in this area, particularly in the extreme southwest and northwest corners, and the tracks are oriented predominantly north-northeast-south-southwest, which further detracts from obtaining accurate bathymetry. However, the SEASAT-derived gravity field prepared by W. Haxby (Haxby et al., 1983; Haxby, 1987) (Fig. 4) was used as a guide in contouring the limited data set. In several instances, strong SEASAT anomalies that exist in 


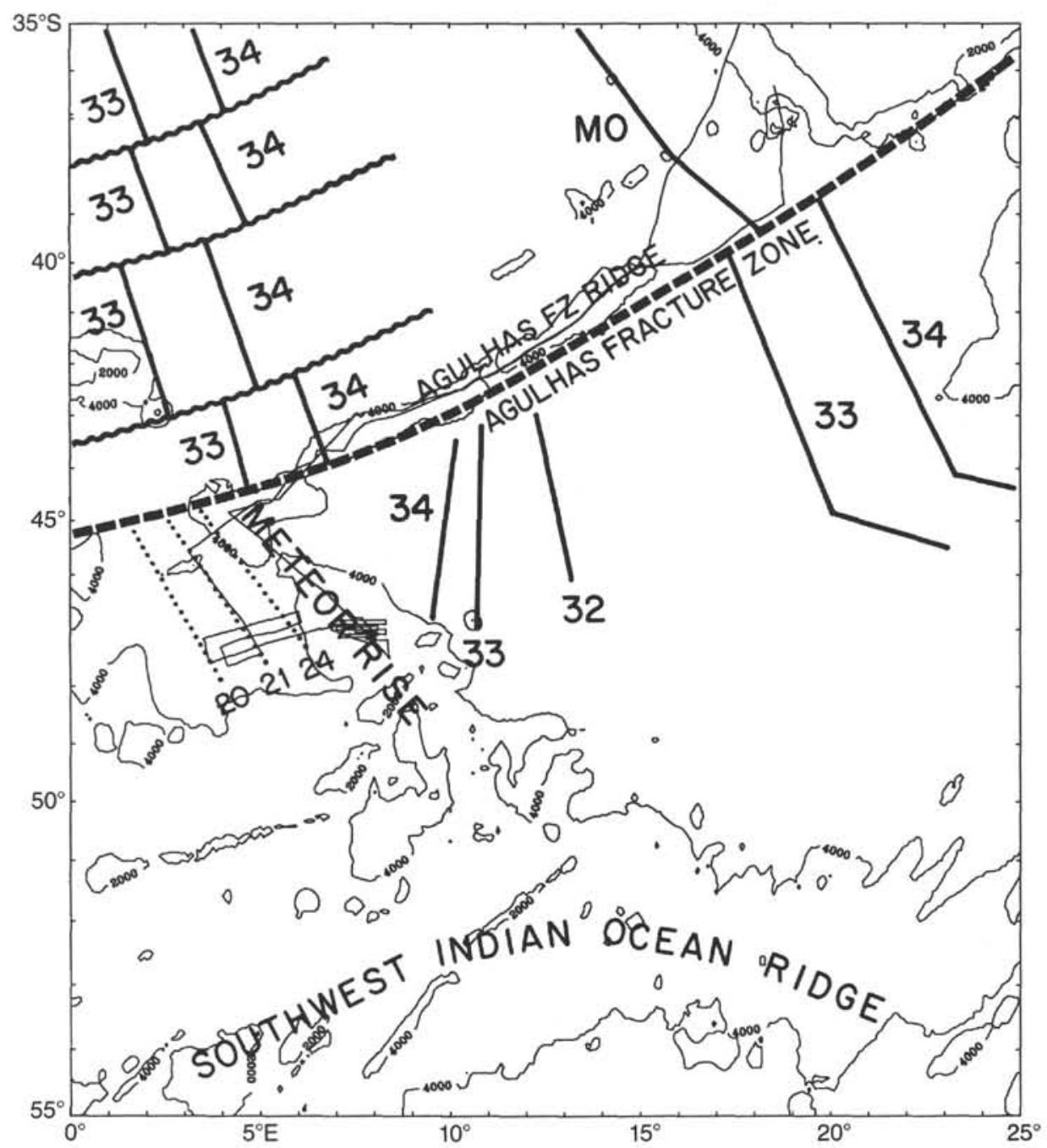

Figure 1. Schematic tectonic map of the Agulhas Basin with the cruise track for Conrad 2710 superimposed. Bathymetric contours were generated from a SYNBAPS digital bathymetry file, updated to include the most recent GEBCO bathymetry (LaBrecque et al., 1981). The Agulhas Fracture Zone is indicated by a heavy dashed line, and fracture zones of the African plate are indicated by wavy lines. Contours in meters.

nonsurveyed areas were used to extend contours and also to infer the presence of seamounts where strong positive anomalies occur in proximity to other mapped seamounts. The seamounts inferred from the SEASAT gravity field are represented by dashed contours on the map. The following sections summarize our observations on the morphology and geophysical signatures of the Agulhas FZ Ridge and Meteor Rise.

\section{AGULHAS FRACTURE ZONE RIDGE}

The Agulhas FZ Ridge was surveyed from its inception at $\sim 40^{\circ} \mathrm{S}, \sim 15^{\circ} \mathrm{W}$, to its intersection with the Meteor Rise in an attempt to establish the minimum depth of the ridge along its entire length. The ridge can be subdivided into two main provinces on the basis of morphology. The eastern province of the ridge bounds crust of middle Cretaceous age on the African plate $\left(\sim 40^{\circ} \mathrm{S}, \sim 15^{\circ} \mathrm{E}\right.$, to $\left.42.75^{\circ} \mathrm{S}, 9.5^{\circ} \mathrm{E}\right)$ and is very shallow and continuous. This eastern ridge province begins near the tip of the abandoned ridge segment and ends where the age offset across the fracture zone is decreased to almost zero. The crust south of the fracture zone is estimated to be $\sim 90 \mathrm{Ma}$ at the boundary between the eastern and western ridge provinces, based on the magnetic anomalies presented in LaBrecque and Hayes
(1979), which are shown in Figure 1. At its extreme eastern end, the ridge is a broad feature at the fossil ridge transform intersection, with $2250-\mathrm{m}$ relief above the average seafloor depth in the area. It narrows considerably toward the southwest, gradually becoming deeper and more diffuse.

The western province, between $42.75^{\circ} \mathrm{S}, 9.5^{\circ} \mathrm{E}$, and $43.8^{\circ} \mathrm{S}$, $6.25^{\circ} \mathrm{E}$, consists of scattered seamounts reaching depths of 2000 $\mathrm{m}$ on a platform averaging $4000 \mathrm{~m}$ in depth. This part of the fracture zone appears to be less affected by the processes which have created the relief of the eastern province.

Southwest of the western ridge province, bordering Eocene age crust of the African plate, the water depth reaches $4250 \mathrm{~m}$, and the seafloor gently slopes to the north. No shallow ridge was found along the fracture zone in this area; however, relief may exist in the unsurveyed area north of the cruise track. A large seamount marks the intersection of the Agulhas Fracture Zone with the trend of the Meteor Rise, and a deep sedimentfilled channel separates the Meteor Rise from this seamount. Despite the difference in its character from east to west, the Agulhas FZ Ridge clearly delineates the fossil plate boundary which formerly was active as a strike-slip zone between the African and Malvinas plates. LaBrecque and Hayes (1979), upon analysis of the existing magnetic and topographic data base in 


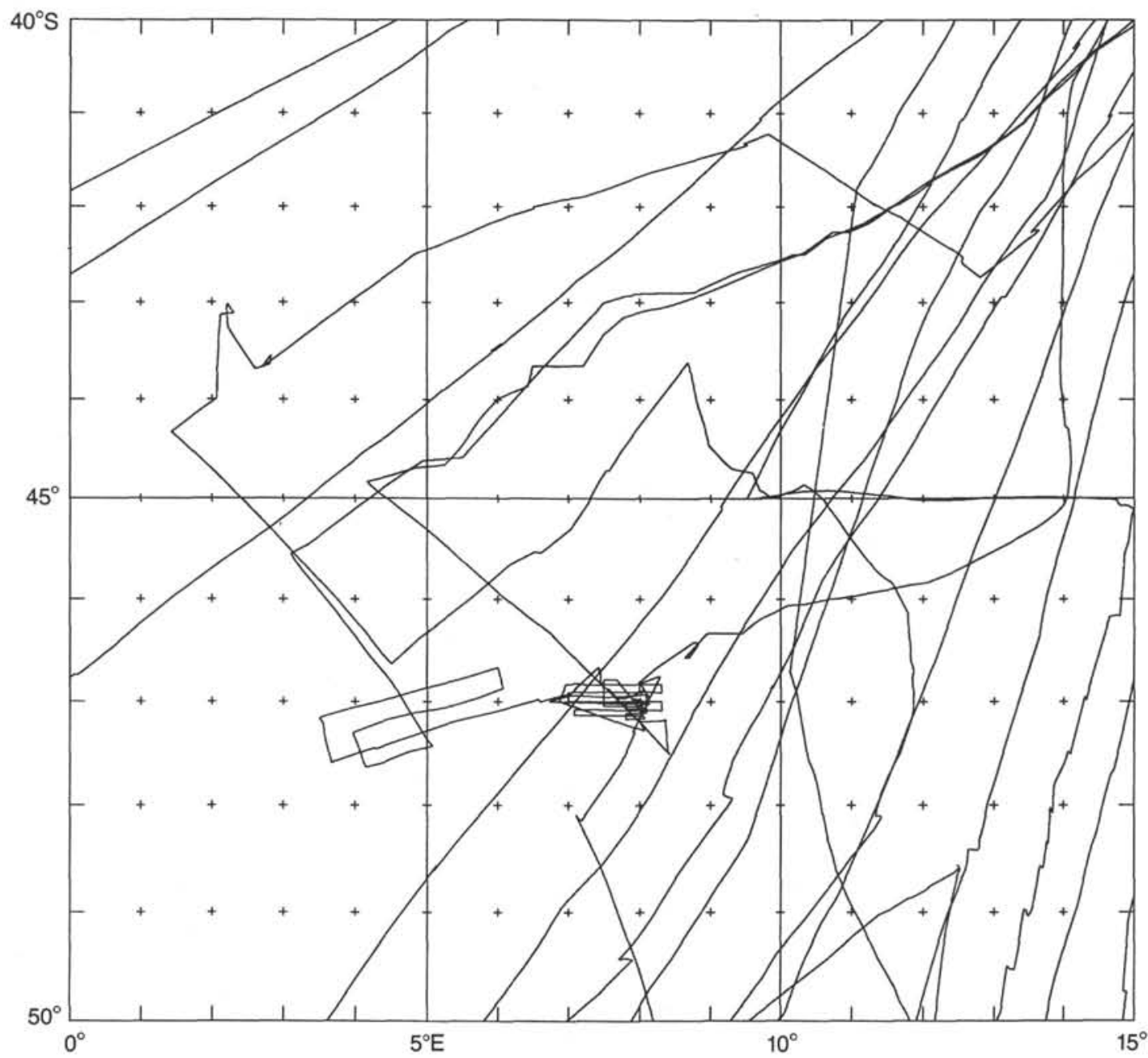

Figure 3. Track chart illustrating the digital bathymetric data base available for compiling the revised map in Figure 2.

the Agulhas basin, concluded that the southward divergent Late Cretaceous magnetic lineation pattern in the Agulhas basin resulted from seafloor spreading in the basin about a pole of rotation different from that of South America-African spreading. They proposed the existence of an additional, short-lived plate which was active from some time before anomaly 34 (estimated to be $\sim 90 \mathrm{Ma}$ ) until the spreading axis relocated and spreading ceased within the Agulhas basin around chron 29R ( $\sim 65 \mathrm{Ma})$. This transient plate, which they named the Malvinas plate, would have comprised one plate of a triple junction with the Indian plate and the Antarctic plate, (the proto-Bouvet triple junction), and moved relative to South American and African plates across the Agulhas fracture zone.

The Seasat-derived gravity field, shown as a gridded, contoured field in Figure 4, provides a useful criteria for locating the fracture zone trace. The position of the paleo strike-slip zone has been identified in the satellite passes; it is located south of the Agulhas FZ Ridge.

The SEASAT gravity gradient is steepest in the eastern province, where the topography is most pronounced and the age offset across the fracture zone is greatest. The gradient decreases and changes polarity over the western province. The age offset that causes the gravity anomaly across the fracture zone (thermal edge effect; Sandwell (1984)) cannot be used to account entirely for the gravity anomalies observed over the eastern ridge province. Over the western ridge province, the gravity anomalies are more subdued, consistent with the small age offset across the fracture zone in this area. The gradient west of the Meteor
Rise along the Agulhas Fracture Zone has the same polarity as the gradient over the eastern province, which is consistent with the sense of the age offset.

The cause of the pronounced relief on the Agulhas FZ Ridge cannot be ascertained from the limited data at hand. It is possible, however, to evaluate several of the mechanisms that might have produced the relief. Bonatti (1978) discussed the occurrence of anomalous topographic highs, elongated parallel to transform faults and fracture zones, that were termed "transverse ridges" by van Andel et al. (1971). Bonatti (1978) recognized the association of the transverse ridges with "primary transform faults" (fracture zones), which Gilliland and Meyer (1976) and others described as offsets generated during the initial rifting of the continents. Bonatti (1978) offered several possible explanations for transverse ridges, including (1) formation in response to small changes in spreading direction, resulting in a horizontal component of compression/extension across the fracture zone (Menard and Atwater, 1968, 1969); (2) horizontal heat conduction; (3) viscodynamic forces (Sleep and Biehler, 1970); and (4) serpentinite diapirism. The Agulhas Ridge qualifies as a transverse ridge, and the Falkland-Agulhas Fracture Zone is obviously in the class of primary transform faults discussed by Gilliland and Meyer (1976). In the following section, we evaluate these mechanisms in consideration of the Agulhas Ridge data.

Several characteristics of the Agulhas Ridge provide constraints on its origin: (1) the relief is on the older plate (determined from SEASAT altimetry); (2) the ridge is asymmetrical, 


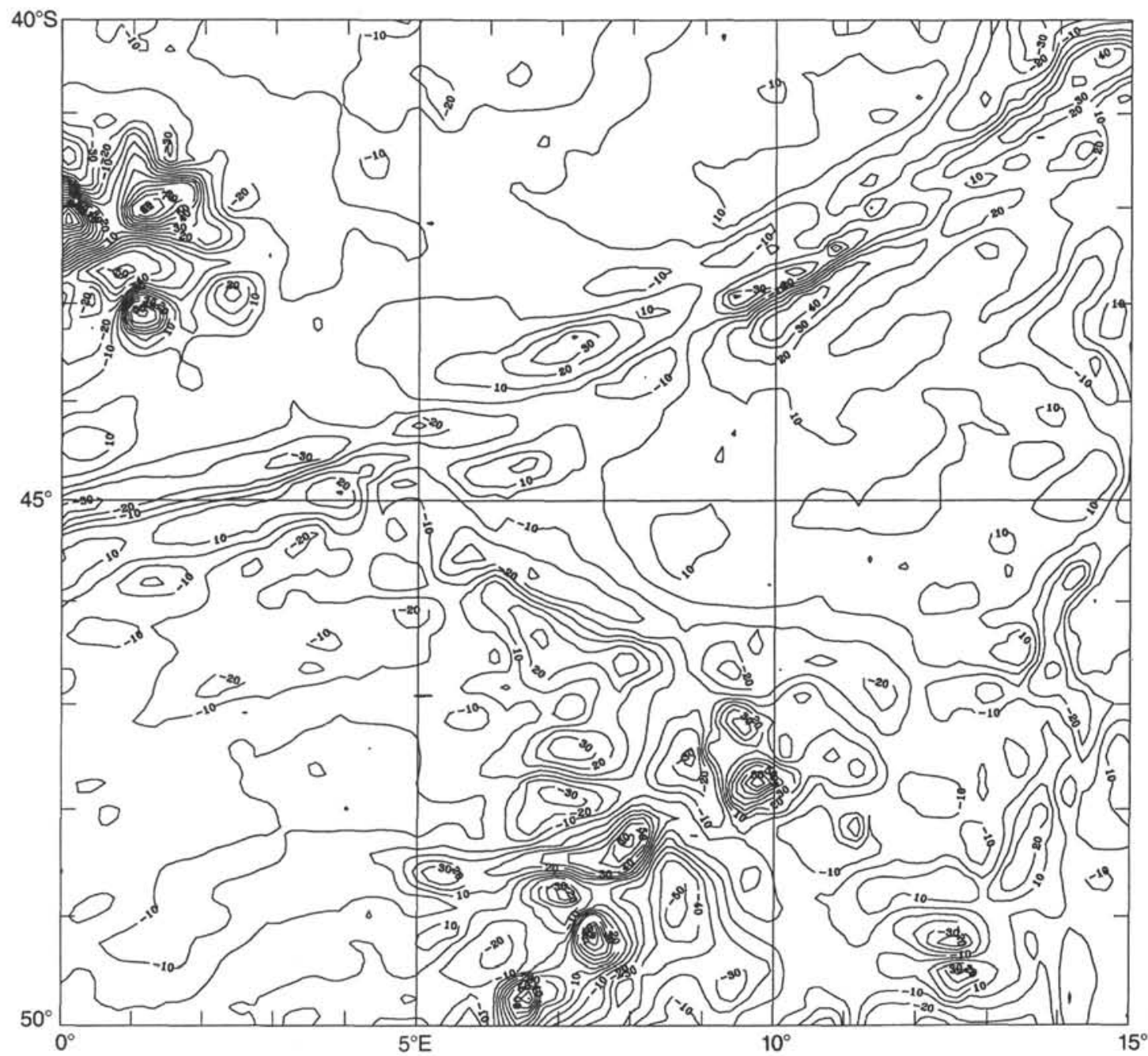

Figure 4. Contour map of the SEASAT gravity field (Haxby, 1987). Contour interval is 10 mgals. Note the correlation between the SEASAT gravity and bathymetry in this region, especially within seamount populations. The strong gradient in the field associated with the Agulhas Fracture Zone is observed where the Agulhas Ridge is most prominent $\left(15^{\circ} \mathrm{E}, 40^{\circ} \mathrm{S}\right.$, to $9.5^{\circ} \mathrm{E}, 43.2^{\circ} \mathrm{S}$ ). A subdued gradient with reverse polarity occurs between $9.5^{\circ} \mathrm{E}, 43.2^{\circ} \mathrm{S}$, up to the intersection with the Meteor Rise at $\sim 5^{\circ} \mathrm{E}, 44.5^{\circ} \mathrm{S}$, where the Agulhas Ridge deepens and widens.

with a steep south-facing wall; and (3) the zone with the most prominent relief appears to be associated with the extinct spreading axis in the Agulhas Basin. The abrupt eastern and western boundaries of the Agulhas Ridge, as well as the existence of the conjugate Falkland Fracture Zone Ridge (see Brenner and LaBrecque, this volume), argue against horizontal heat conduction as a mechanism for forming the transverse ridges. If heat conduction were responsible for the relief, then we would expect to see an even shallower fracture zone ridge east of the Agulhas FZ Ridge, where the age contrast across the fracture zone is even greater, and theoretically, the thermal contrast is greater. Serpentinite diapirism cannot be ruled out; however, no lithologic information is available for the ridge to substantiate this hypothesis. Serpentinization at fracture zones would take place more easily where thinner crust had allowed seawater to penetrate into the lower crust/upper mantle along faults in the transform valley. Thinned crust has been documented at the Kane Fracture Zone (KFZ) in the North Atlantic and is associated with the KFZ transverse ridge (Abrams et al., 1988). However, Abrams et al. (1988) used the evidence of a positive isostatic gravity anomaly over the transverse ridge to preclude the existence of a low-density serpentinite protrusion under the ridge.
We leave open the possibility that thin crust and serpentinite diapirism may have contributed to the relief on the Agulhas FZ Ridge.

The occurrence of seafloor spreading in the Agulhas Basin oblique to the established direction of the Agulhas Fracture Zone would have resulted in a component of deviatoric compressive or tensile stress across the fracture zone (Menard and Atwater, 1968, 1969). The existence of the Malvinas plate, as discussed by LaBrecque and Hayes (1979) and LaBrecque (1986), implies that relative motion occurred between the Malvinas and South American plates from the Late Cretaceous (pre-anomaly 34 ) until the ridge jump at $\sim 65 \mathrm{Ma}$, with a small component of the convergence/extension between the African and Malvinas plates occurring across the Agulhas Fracture Zone. Both the association of the prominent relief on the Agulhas FZ Ridge (the eastern province) with the extinct ridge axis and the trend of the extinct ridge axis (inferred from SEASAT-derived gravity anomalies; Haxby, 1987) are consistent with spreading at the extinct axis in the Agulhas Basin occurring oblique to the direction of South America-Africa relative motion.

Therefore, we propose that the relief on the Agulhas Fracture Zone was most likely caused by small changes in the direc- 
tion of seafloor spreading that occurred from the Late Cretaceous until $\sim 65 \mathrm{Ma}$ south of the Agulhas Fracture Zone. In this scenario, the transverse ridge was generated by tectonic uplift (compression) or volcanic construction (extension). Because the magnetic anomaly data in the Agulhas Basin are not sufficiently dense for precise determination of the spreading direction or its variation with time, we cannot distinguish whether compression, extension, or a combination of both occurred across the fracture zone.

\section{METEOR RISE}

The Meteor Rise is a broad plateau reaching depths of 2500 $\mathrm{m}$, upon which shallower, rougher topography is situated. A small sedimentary basin atop the Meteor Rise was the primary target of the site survey and was surveyed with $20-\mathrm{km}$ track spacing. A region of very rough topography flanking the eastern edge of the basin was surveyed with nearly continuous Sea Beam coverage. The very shallow depths observed in this seamount province, which is bounded to the east by a steep scarp, result in an asymmetrical cross section for the Meteor Rise (see seismic line of Fig. 1, "Site 703" chapter, this volume). This cross-sectional asymmetry agrees with predictions of melt volume generated at developing rifts by LaBrecque and Zitellini (1985), based on magnetic anomalies in the Red Sea, and Mutter et al.'s (1988) model of small-scale convection. The average depth of the conjugate Islas Orcadas Rise is approximately 500$1000 \mathrm{~m}$ deeper than the Meteor Rise. This apparent depth asymmetry between the two rises can be accounted for by considering the regional depth anomaly within the Agulhas Basin. The average depth of the African plate is approximately $600 \mathrm{~m}$ shallower than the South American plate in the southern South Atlantic (Hayes, 1988). Subtracting this regional depth anomaly from the depth of the Meteor Rise restores the symmetry between the two rises, which supports the idea that they formed as a consequence of rifting of old ( $\sim 25 \mathrm{Ma})$ oceanic lithosphere following the relocation of the spreading axis.

Magnetic anomaly and free air gravity profiles for the southern Meteor Rise are shown superimposed on the revised bathymetry in Figures 5 and 6, respectively. The basement of the rise is normally magnetized, as evidenced by the positive correlation between magnetic anomaly and bathymetry (or basement in sedimented areas). However, the volcanic edifice on the eastern edge of the rise displays a negative correlation of magnetic anomaly with bathymetry, indicating formation or remagnetization during a reversed polarity epoch (Fig. 5). Hole 703A was drilled in this edifice and volcanic basement was recovered overlain by sediment of early Eocene age. The limited data prevent determination of whether the seamounts formed contemporaneously with the remainder of the rise, in which case they would record a reversal of the Earth's magnetic field, or if they formed during a later phase of volcanism, distinct from the formation of the major rise structure. The lower Eocene sediment overlying basement at Site 703 indicates that the age of the volcanism is early Eocene or older (see "Site 703" chapter, this volume).

The gravity profiles clearly delineate the dimensions of the sedimentary basin, which is characterized by a negative free air anomaly (Fig. 6). The gravity profiles suggest the presence of a flexural moat west of the seamount province within the sedimentary basin, which would imply loading of the Meteor Rise by the seamount volcanism. However, without a symmetric gravity profile, it is very difficult to model a flexural response. It is possible that the flexural downwarping of the rise as a result of seamount volcanism could have influenced the deposition of sediments in the basin.

\section{MAGNETIC ANOMALIES}

A survey line was run along an estimated flowline from the Meteor Rise into the eastern South Atlantic Ocean. Data reduction aboard ship allowed us to accurately identify the anomaly sequence $24-20$, and we were able to place a track along the anomaly 21 stripe for several hundred kilometers. The lineation direction was thus established as $\sim 324^{\circ}$, which is nearly coincident with that shown in the OMD Region 13 Synthesis (LaBrecque, 1986). The oldest identifiable anomaly west of the Meteor Rise is C24R ( $55 \mathrm{Ma})$, and the southwestern margin appears to be isochronous. The magnetic anomaly data on the Meteor Rise are insufficient to determine if seafloor spreading type anomalies exist on the Rise. The isochroneity of the western margin of the rise argues against a slow southward propagation of the South Atlantic spreading center as an explanation of the fanning anomalies in the Agulhas basin; however, the data distribution is too sparse to resolve if fanning lineations exist in older crust of the Meteor Rise.

\section{CONCLUSIONS}

The Agulhas Basin contains many anomalous tectonic elements. Consideration of the Sea Beam bathymetry and geophysical data collected during the site survey cruise has greatly improved our understanding of the morphotectonic elements of the basin. If we assume that the Agulhas FZ Ridge formed early in the evolution of the basin, its relief would have significantly inhibited interbasin circulation between the South Atlantic and antarctic water masses. Breaks present in the relief may have served as pathways to allow communication between the two water masses; a significant gap exists near the intersection of the Agulhas FZ Ridge with the Meteor Rise. Additional relief possibly exists in the unsurveyed area north of our track. The morphology of the Agulhas FZ Ridge and its relationship to the Falkland Fracture Zone ridge support the argument that the primary cause of relief on the fracture zone was a change in the direction of seafloor spreading from the Late Cretaceous to the time of the ridge crest jump (late Maestrichtian-early Paleocene). This time frame coincides with the proposed existence of the Malvinas plate, which obviates the need for nonrigid plate tectonics to explain the fan-shaped pattern of magnetic anomalies in the Agulhas Basin. The less intense relief of the western ridge province may indicate that spreading was only slightly oblique at first and became more oblique with time until the ridge crest jumped westward.

The Meteor Rise is a very shallow feature, much more so than previously mapped. Paleodepth estimates place the rise at or above sea level until the middle Eocene. The asymmetrical shape of the Meteor Rise can be attributed to effusive volcanism at the new rift zone, which tapered off as the rift developed (LaBrecque and Zitellini, 1985; Mutter et al., 1988). The difference between the average depths of the Islas Orcadas Rise in the Georgia Basin (see Brenner and LaBrecque, this volume) and the Meteor Rise can be explained as a consequence of regional depth anomalies in the southern South Atlantic. Sedimentation on the Meteor Rise may have been influenced by downwarping of the eastern edge of the rise as a result of the loading of finite strength crust during a later phase of volcanism. Drilling results from the Meteor Rise, combined with geophysical data, will be used to refine models describing the formation of the Meteor Rise and the tectonic evolution of the Agulhas Basin.

\section{ACKNOWLEDGMENTS}

The authors wish to thank Captain Roberge and the crew of the Conrad for making the cruise both enjoyable and highly successful, de- 


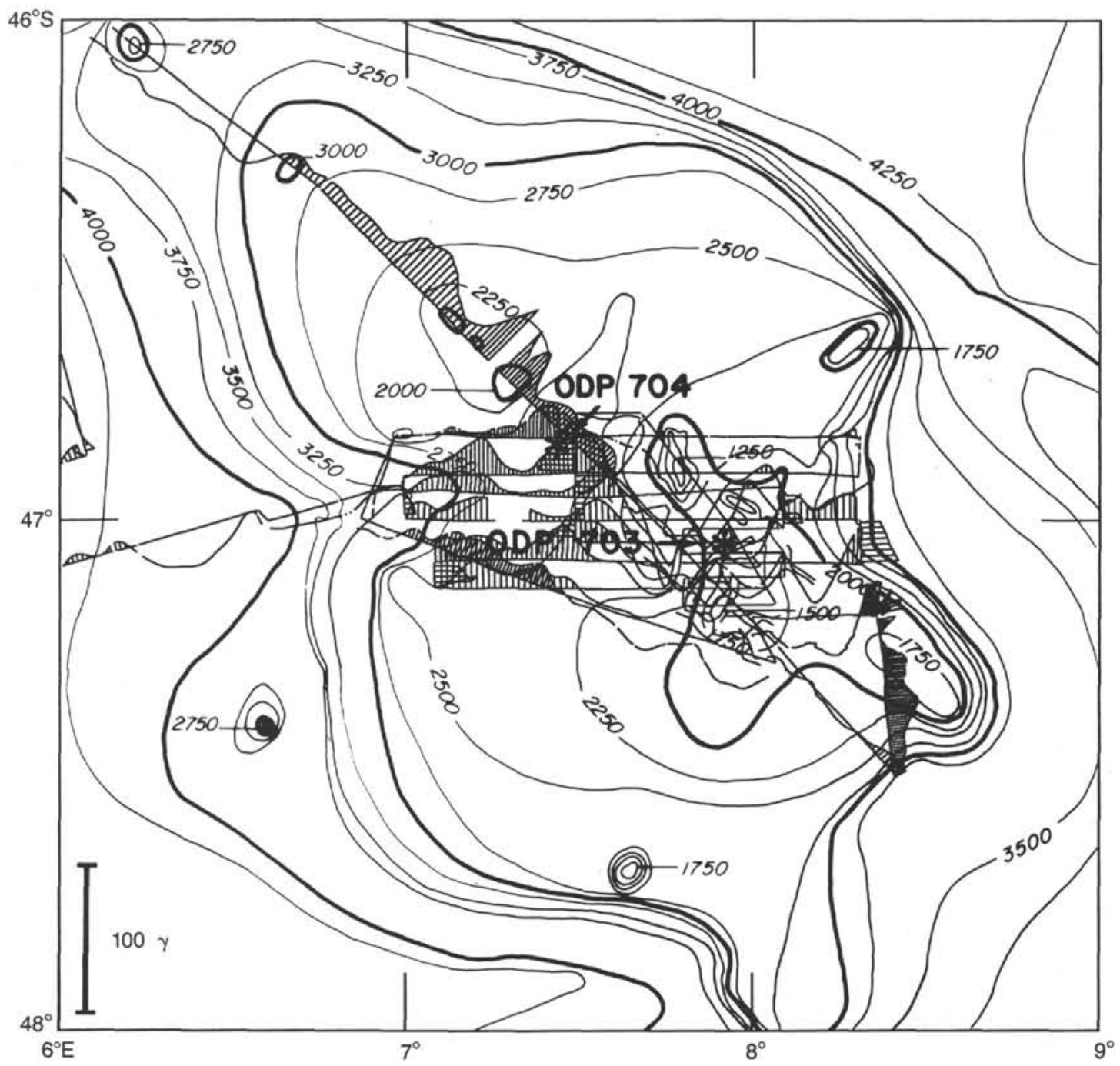

Figure 5. Magnetic anomaly profiles over the Meteor Rise plotted on revised bathymetry. Note the contrast between the seamounts and the sedimentary basin. Contours in meters.

spite the weather. We are also indebted to Carl Brenner for technical assistance and fruitful discussions. Bill Haxby kindly lent his expertise in evaluating the satellite gravity data. The manuscript was improved by a review by Kim Kastens. This research was supported by the National Science Foundation, contract OCE-85-07681.

\section{REFERENCES}

Abrams, L. J., Detrick, R. S., and Fox, P. J., 1988. Morphology and crustal structure of the Kane Fracture Zone transverse ridge. J. Geophys. Res., 93:3195-3210.

Barker, P. F., 1979. The history of ridge-crest offset at the Agulhas Fracture Zone from a small-circle geophysical profile. Geophys. J. R. Astron. Soc., 59:131-145.

Bonatti, E., 1978. Vertical tectonism in oceanic fracture zones. Earth Planet. Sci. Lett., 37:369-379.

du Plessis, A., 1977. Seafloor spreading south of the Agulhas Fracture Zone. Nature, 270:719-721.

Gilliland, W. N., and Meyer, G. P., 1976. Two classes of transform faults. Geol. Soc. Am. Bull., 87:1127-1130.

Hayes, D. E., 1988. Age-depth relationships and depth anomalies in the Southeast Indian Ocean and South Atlantic Ocean. J. Geophys. Res., 93:2937-2954.

Haxby, W. F., 1987. Gravity Field of the World's Oceans (map): Boulder, CO (NOAA/NGDC).
Haxby, W. F., Karner, G. D., LaBrecque, J. L., and Weissel, J. K., 1983. Digital images of combined oceanic and continental data sets and their use in tectonic studies. EoS, Trans. Am. Geophys. Union, 64: 995-1004.

Kent, D. V., and Gradstein, F. M., 1986. A Jurassic to Recent chronology. In Tucholke, B. E., and Vogt, P. R. (Eds.), The Geology of North America: The Western Atlantic Region: Geol. Soc. Am. DNAG Ser., 1:45-50.

LaBrecque, J. L. (Ed.), 1986. South Atlantic Ocean and Adjacent Continental Margin, Atlas 13: Ocean Margin Drilling Program Reg. Atlas Ser., 13.

LaBrecque, J. L., and Hayes, D. E., 1979. Seafloor spreading history of the Agulhas basin. Earth Planet. Sci. Lett., 45:411-428.

LaBrecque, J. L., Rabinowitz, P. D., and Brenner, C., 1981. General Bathymetric Chart of the Oceans (GEBCO 5:16): Ottawa (Canadian Hydrographic Office).

LaBrecque, J. L., and Zitellini, N., 1985. Continuous seafloor spreading in the Red Sea: an alternative interpretation of magnetic anomaly pattern. AAPG Bull., 4:513-524.

Menard, H. W., and Atwater, T., 1968. Changes in direction of seafloor spreading. Nature, 219:463-467. 1040. 1969. Origin of fracture zone topography. Nature, 222:1037-

Mutter, J. C., Buck, W. R., and Zehnder, C. M., 1988. Convective partial melting. 1. A model for the formation of thick basaltic se- 
quences during the initiation of spreading. J. Geophys. Res., 93: 1031-1048.

Parsons, B., and Sclater, J. G., 1977. An analysis of the variation of oceanic bathymetry and heat flow with age. J. Geophys. Res., 83: 803-827.

Sandwell, D. 1986. Thermomechanical evolution of oceanic fracture zones. J. Geophys. Res., 89:11401-11413.

Sleep, N. H., and Biehler, S., 1970. Topography and tectonics at the intersections of fracture zones with central rifts. J. Geophys. Res., 75: 2748-2752. van Andel, T. H., Von Herzen, R. P., and Phillips, J. D., 1971. The Vema Fracture Zone and the tectonics of transverse shear zones in oceanic crustal plates. Mar. Geophys. Res., 1:261-283.

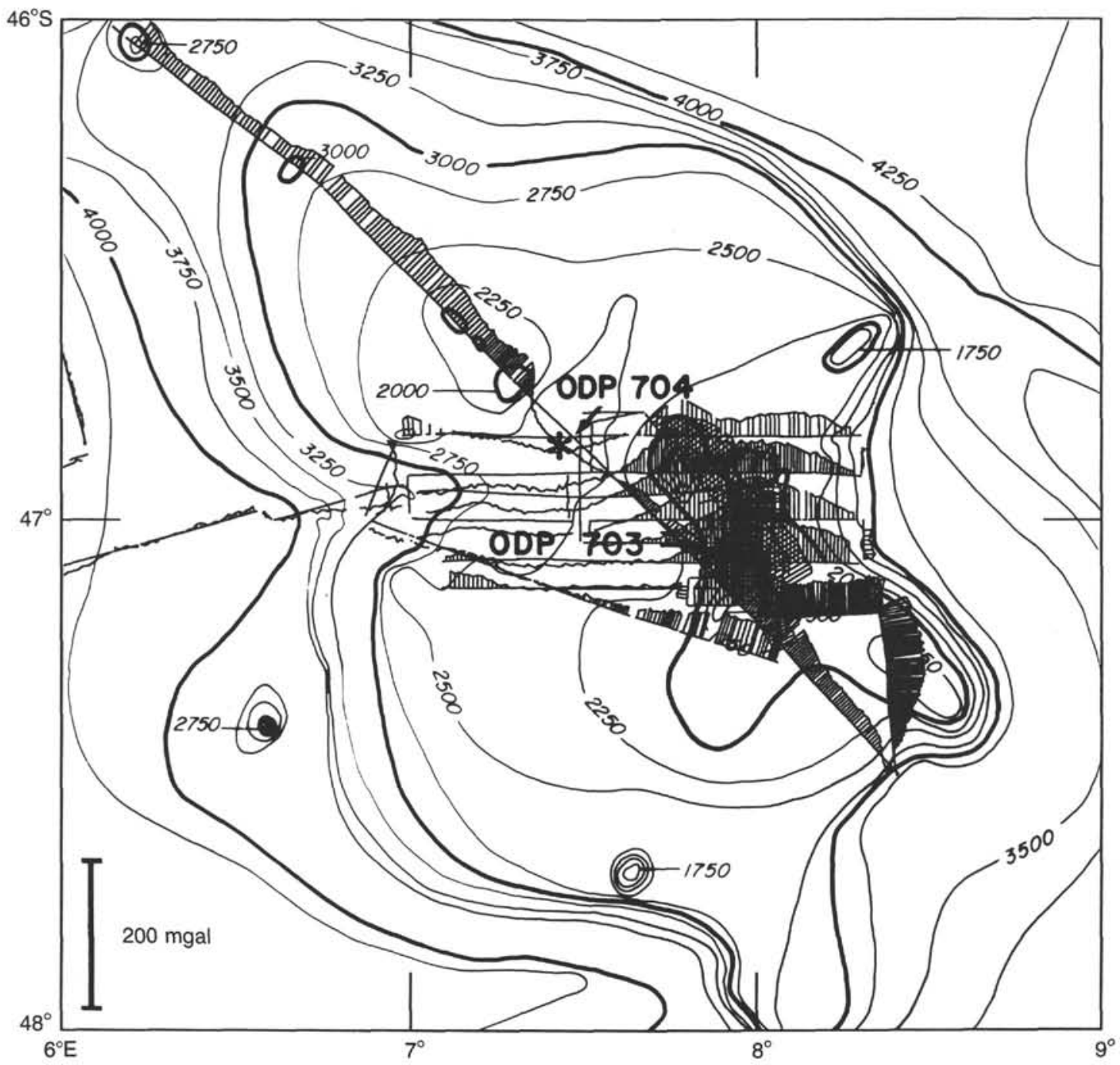

Figure 6. Gravity profiles plotted on revised bathymetry. A negative gravity anomaly defines the geometry of the sedimentary basin. Contours in meters. 